\section{Kandungan Kadar Air dan Kadar Protein pada Bakso Ayam Broiler dengan Putih Telur Sebagai Bahan Pengenyal pada Konsentrasi yang Berbeda}

\author{
Munassir B \\ Nurhaeda \\ Irmayani
}

\begin{abstract}
Abstrak. Penelitian ini bertujuan untuk mengetahui pengaruh putih telur pada konsentrasi yang berbeda terhadap kandungan kadar air dan kadar protein pada bakso ayam broiler. Penelitian ini menggunakan Rangcangan Acak Lengkap (RAL) dengan ulangan sebanyak tiga kali dan perlakuan sebanyak empat kali yaitu $T 0=$ Kontrol, $T 2=15$ gram Putih Telur, $T 2=30$ gram Putih Telur, $73=75$ gram Putih Telur. Analisis Ragam menunjukkan penambahan putih telur sebagai bahan pengeyal pada konsentrasi yang berbeda berpengaruh nyata terhadap kandungan kadar air dan tidak berpengaruh nyata terhadap kandungan kadar protein. Rata - rata kandungan kadar air pada bakso ayam broiler tertinggi ke terendah diperoleh dari perlakuan P3 sebesar ( 61,48\%), P0 $(58,48 \%$ ), P1 (53,58 \% ), dan P2 (43,32\%). Rata - rata kandungan kadar protein pada bakso ayam broiler terendah ke tertinggi diperoleh dari perlakuan PO ( $12,54 \%)$, P2 (13,29 \% ), P1 (14,13\% ), dan P3 (15,32 \%). Dari hasil penelitian kandungan kadar air dan kadar protein dengan putih telur sebagai bahan pengeyal yang berbeda yang terbaik yaitu 43 gram putih telur. Kandungan kadar air terbaik diperoleh pada perlakuan P2 dengan nilai ratarata 43,32\%. Kandungan kadar protein terbaik diperoleh pada perlakuan P3 dengan nilai rata-rata $15,32 \%$.
\end{abstract}

Kata Kunci: broiler, putih telur, kadar air, kadar protein

\section{Pendahuluan}

Daging merupakan bagian dari hewan potong yang digunakan manusia sebagai bahan makanan, selain mempunyai penampakan yang menarik selera, juga merupakan sumber protein hewani berkualitas tinggi. Daging adalah makanan yang berkualitas tinggi. Dalam daging terdapat asam amino esensial yang diperlukan tubuh, sehingga diharapkan selalu ada dalam makanan (Lawrie, 2003).

Bakso merupakan produk olahan daging yang popular di masyarakat dan mempuyai harga yang relatif murah sehingga dapat dijangkau oleh masyarakat. Dengan kebiasaan mengosumsi bakso ini diharapkan kebutuhan protein masyarakat dapat dipenuhi sehingga dapat meningkatkan nilai gizi masyrakat pada umumnya (Ngudiwaloyo et al., 2007).

Fungsi daging ayam dalam pembutan bakso ini adalah sebagai bahan utama yang merupakan bagian penting dalam pembuatan bakso. Ayam merupakan ternak penghasil daging dan telur. Jenis ayam pendaging biasa digunakan adalah Broiller yang dapat dibedakan berdasarkan umur ayam yang dipotong. Daging ayam merukan sumber protein yang cukup penting bagi tubuh. Daging ayam memiliki kandungan protein yang lebih tinggi. (Purnomo, 2005).

Pada proses pengolahan bakso sering ditambahkan Bahan Tambahan Makanan (BTM) tertentu, antara lain Sodium Tripoly Phospat (STP), karagenan, putih telur

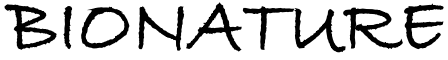

\author{
p-ISSN 1411 - 4720 \\ e-ISSN 2654 - 5160
}

Abstract. This study aims to determine the effect of egg white at different concentrations on the content of water content and protein content in broiler chicken meatballs. This research uses Completely Randomized Rangcangan (CRD) with three replications and treatment four times, namely $\mathrm{T0}=$ Control, T2 = 15 grams of Egg White, T2 = 30 grams of Egg White, T3 = 75 grams of

White Egg. Variety analysis showed the addition of egg whites as pengeyal material at different concentrations significantly affected the content of water

content and did not significantly affect the content of protein content. The

average water content in the highest to lowest broiler chicken meatballs was obtained from P3 treatment of (61.48\%), $P 0$ (58.48\%), P1 (53.58\%), and P2 (43.32\%). The average protein content in the lowest broiler chicken meatballs was obtained from treatment $P 0$ (12.54\%), P2 (13.29\%), $P 1$ (14.13\%), and P3 (15.32\%).

From the results of research the content of water content and protein content with egg whites as different pengeyal

ingredients is 43 grams of egg white. The best water content obtained in $P 2$ treatment with an average value of $43.32 \%$. The best protein content obtained in P3 treatment with an average value of $15.32 \%$

Keywords: broiler, egg white, moisture content, protein content.

Munassir B

Universitas Muhammadiyah Parepare Indonesia

Nurhaeda

Universitas Muhammadiyah Parepare Indonesia

Irmayani Universitas Muhammadiyah Parepare Indonesia 
(albumen) dan soda kue (NaHCO3) yang berfungsi sebagai bahan pengenyal. Putih telur merupakan bahan pengenyal yang alami, sedangkan soda kue merupakan bahan pengenyal sintetis yang diizinkan. Putih telur (albumen) mengandung jumlah protein yang tinggi dan kalau dipanaskan akan menggumpal, membentuk gel dan mengkompakkan daging. Soda kue bila dipanaskan, asamnya akan bereaksi dan membentuk garam, air dan gas yang akan menyebabkan mengembangnya bahan (Amrullah, 2004).

Selain bahan pengenyal alami dan sintetis yang dizinkan tersebut, ada juga produsen bakso yang masih menggunakan bahan pengenyal yang dilarang seperti boraks. Hal ini dilakukan oleh produsen untuk mengejar keuntungan yang lebih besar, karena bahan tersebut sangat murah dan mudah didapat, padahal bahan tersebut sangat berbahaya bagi kesehatan manusia. Boraks merupakan kristal putih yang lunak, bila ditambahkan dalam produk daging akan menghasilkan produk yang kesat dan kenyal teksturnya.

Berdasarkan uraian diatas, maka perlu dilakukan penelitian dengan tujuan untuk mengetahui kadar air dan kadar protein bakso daging ayam yang diberi bahan pengenyal putih telur. Hasil penelitian ini diharapkan dapat menjadi bahan komparasi tentang bakso yang diproduksi dan diproses secara benar dan higienis, sehingga dapat menjadi sumber informasi bagi konsumen guna memperoleh produk bakso dengan kualitas yang baik.

\section{Metode Penelitian}

\section{Waktu dan Tempat Penelitian}

Penelitian ini dilaksanakan pada bulan Juli - Agustus 2018 di Labotarium Fakultas Pertanian Peternakan dan Perikanan Universitas Muhammadiyah Parepare dilakukan pembuatan bakso ayam kemudian bakso ayam di analisis di Labotrium Kimia Makanan Ternak Fakultas Peternakan Jurusan Nutrisi Ternak Universitas Hasanuddin Makassar (UNHAS).

\section{Desain Penelitian}

Penelitian ini menggunakan Rancangan Acak Lengkap (RAL) dengan 4 taraf perlakuan dan 3 kali pengulangan T0 (sebagai kontrol), T1, T2 dan T3, hingga terdapat 12 unit pengamatan dan setiap unit terdiri dari $100 \%$ daging ayam broiler. Penelitian dilaksanakan dengan menggunakan putih telur sebagai bahan pengenyal yang berbeda pada pengolahan daging ayam broiler dengan formula sebagai berikut:

$\mathrm{T} 0=$ Daging Ayam broiler $100 \%$

$\mathrm{T} 1=$ Daging Ayam broiler $100 \%+15$ gram putih telur

T2=Daging Ayam broiler 100\% + 30 gram putih telur

$\mathrm{T} 3=$ Daging Ayam broiler $100 \%+75$ gram putih telur

Nilai rata - rata dari kadar air dan kadar protein bakso daging ayam broiler dengan menggunakan analisis ragam menurut Rangcangan Acak Lengkap ( RAL ). Apabila perlakuan berpengaruh nyata analisis dilanjutkan dengan menggunakan analisis jarak berganda Duncan dengan program statistik SPSS. 


\section{Hasil Penelitian dan Pembahasan}

Kadar Air berikut:

Adapun nilai kadar air dari setiap perlakuan disajiakan dalam tabel dan diagram batang

Tabel 1. Hasil Analisis Bahan Terhadap Kadar Air Bakso Ayam Broiler

\begin{tabular}{|c|c|c|c|c|}
\hline \multirow{2}{*}{ Perlakuan ( T ) } & \multicolumn{3}{|c|}{ Ulangan ( U) } & \multirow{2}{*}{ Total } \\
\cline { 2 - 5 } & $\mathbf{1}$ & $\mathbf{2}$ & $\mathbf{3}$ & 175,45 \\
\hline 0 & 58,56 & 58,31 & 58,58 & 160.75 \\
\hline 1 & 59,03 & 58,79 & 42,93 & 129,97 \\
\hline 3 & 43,06 & 43,57 & 43,34 & 184.37 \\
\hline
\end{tabular}

Sumber: Laboratorium Kimia Makanan Ternak, Fakultas Peternakan, Universitas Hasanuddin, Makassar.

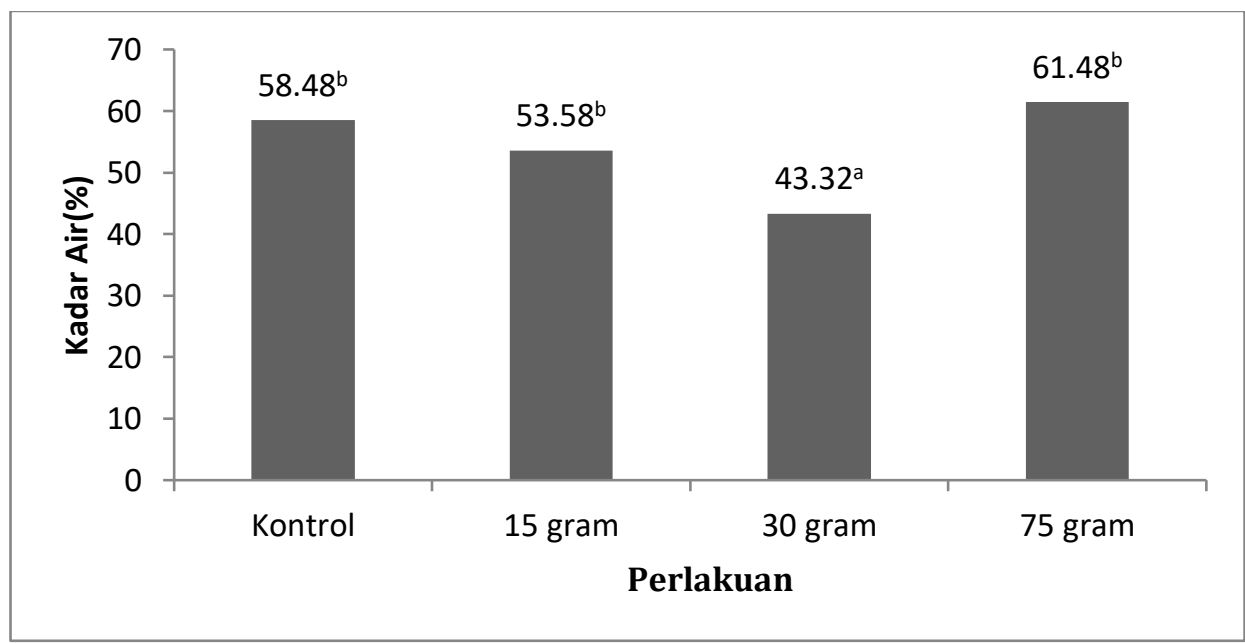

\section{Gambar 1. Nilai Rata-Rata Kadar Air Bakso Ayam Broiler dengan Penambahan Putih Telur Sebagai Bahan Pengenyal}

Berdasarkan hasil analisis statistik menunjukkan bahwa bahan pengenyal pada kolom yang sama berpengaruh nyata $(\mathrm{P}<0,05)$ terhadap kadar air bakso daging ayam. Pada penelitian ini kadar air sudah memenuhi SNI karena kadar air kurang dari 70\% sedangkan pada SNI kadar air maksimal $70 \%$ adapun Kadar air tertinggi diperoleh dari bakso dengan bahan pengenyal putih telur yaitu T3 $\left(61,48 \%{ }^{\mathrm{b}}\right)$, sedangkan kadar air terendah diperoleh dari bakso daging ayam dengan bahan pengenyal putih telur yaitu T2 (43,32\% ). Soeparno (2009) menyatakan bahwa kadar air akan sesuai dengan macam lemak dan bahan pengikat yang ada dalam produk daging dan kemampuan mengikat air serta macam protein dan mineral terutama kalsium dan fosfat dalam produk daging.

\section{Kadar Protein}

Adapun nilai kadar protein dari setiap perlakuan disajiakan dalam tabel dan diagram batang berikut: 
Tabel 2. Hasil Analisis Bahan Terhadap Kadar Protein Bakso Ayam Broiler

\begin{tabular}{|c|c|c|c|c|}
\hline \multirow{2}{*}{ Perlakuan ( T ) } & \multicolumn{3}{|c|}{ Ulangan ( U) } & \multirow{2}{*}{ Total } \\
\cline { 2 - 4 } & $\mathbf{1}$ & $\mathbf{2}$ & $\mathbf{3}$ & \\
\hline 0 & 12,34 & 12,96 & 12,32 & 37,62 \\
\hline 1 & 14,18 & 13,47 & 14,74 & 42,39 \\
\hline 2 & 13,23 & 12,89 & 13,76 & 39,88 \\
\hline 3 & 15,34 & 15,12 & 15,49 & 45,95 \\
\hline
\end{tabular}

Sumber: Laboratorium Kimia Makanan Ternak, Fakultas Peternakan, Universitas Hasanuddin, Makassar.

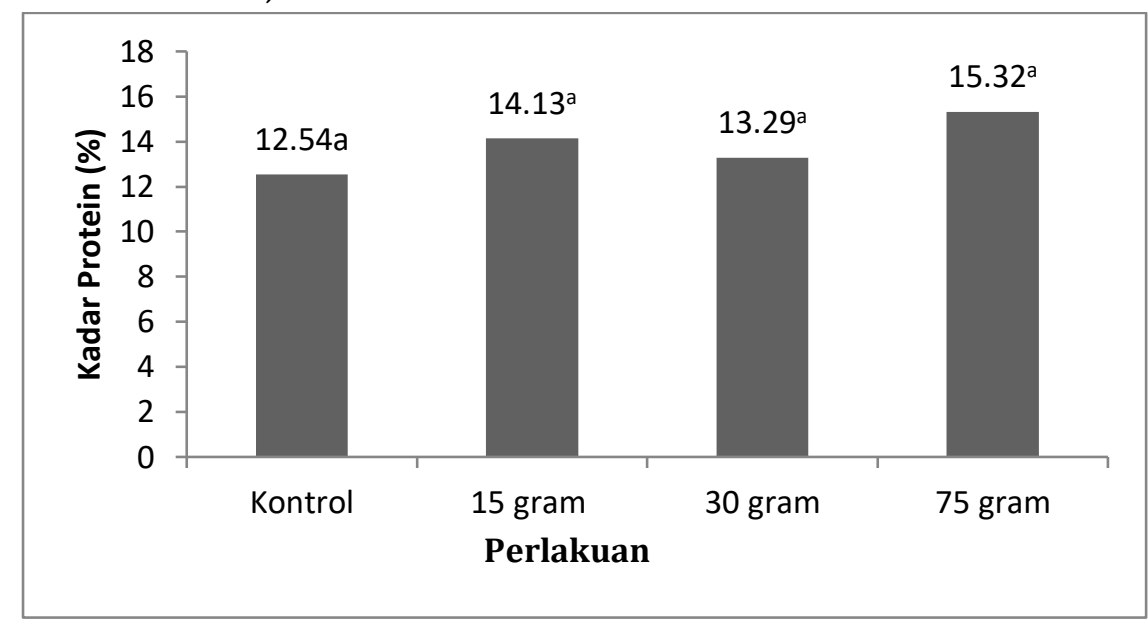

\section{Gambar 2. Nilai Rata-Rata Kadar Protein Bakso Ayam Broiler dengan Penambahan Putih Telur Sebagai Bahan Pengenyal}

Berdasarkan hasil analisis statistik menunjukkan bahwa bahan pengenyal pada kolom yang sama tidak berpengaruh nyata $(p>0,05)$ terhadap kadar protein bakso daging ayam. Pada penelitian ini kadar protein sudah memenuhi SNI karena sudah lebih dari $11 \%$ karena pada SNI kadar protein minimal 11\% adapun Kadar protein tertinggi diperoleh dari bakso dengan bahan pengenyal putih telur yaitu T3 (15,32a) , sedangkan kadar protein terendah diperoleh dari bakso daging ayam dengan Tanpa bahan pengenyal putih telur (kontrol) yaitu T0 (12,54a) . Bakso daging ayam yang menggunakan bahan pengenyal putih telur mempunyai kadar protein yang lebih tinggi karena sifat putih telur yang mengenyalkan dan mengompakkan bakso, sehingga zat-zat termasuk protein daging yang mudah larut (sarkoplasmik) terperangkap dan tidak banyak yang terekstraksi keluar. Menurut Windayani \& Murtini (2006), bahwa bakso yang diberi bahan pengenyal akan lebih kenyal dan kompak bila dibanding dengan control.

Protein adalah komponen penting dari makanan manusia yang dibutuhkan untuk penggantian jaringan, pasoka energy, dan makromolekul serbaguna disistem kehidupan yang mempunyai sistem pointing dalam semua proses biologi seperti sebagai katalis, transportasi, berbagai molekul lain seperti oksigen, sebagai kekebalan tubuh, dan menghantarkan implus saraf (Fredrick, et all., 2013). Rahayu (2016) menyatakan bahwa komponen daging yang besar peranannya dalam pembuatan bakso adalah protein. Protei berfungsi sebagai bahan pengikat hancuran daging selama pemasakan, membentuk struktur yang kompak dan sebagai emulsifier, sehingga dapat mengikat air dan lemak dengan baik. 


\section{Kesimpulan}

Berdasarkan uraian dan hasil penelitian maka dapat disimpulkan bahwa kandungan kadar air dan kadar protein pada bakso ayam broiler dengan putih telur sebagai bahan pengeyal yang berbeda sudah memenuhi SNI. Peran putih telur dalam pembuatan bakso ayam sangat berpengaruh pada kadar air dan kadar protein.

Adapun saran dari penelitian yang diajukan dalam skripsi ini agar kiranya mengembangkan bakso daging ayam karena selain dagingnya yang murah kandungan gizinya juga jauh lebih lengkap dibandingkan dengan daging sapi.

\section{Referensi}

Amrullah. (2004). Suhu Telur. Universitas Muhammadiyah. Semarang.

Lawrie, R.A. (2003). Ilmu Daging. Edisi Kelima. Penerjemah Aminuddin Parakkasi dan Yudha Amwila. Penerbit Universitas Indonesia (UI-Press). Jakarta.

Ngudiwaloyo. (2007). Kandungan Gizi Daging Ayam Broiler. Universitas Muhammadiyah. Semarang.

Purnomo. (2005). Fungsi Daging Ayam dalam Pembuatan Bakso. Universitas Muhammadiyah, Semarang.

Rahayu. (2016). Fungsi Bahan Pengisi Bakso. Universitas Muhammadiyah. Semarang.

Soeparno. (2009). Fungsi Kadar Air pada Bakso Ayam Broiler. http://library.usu.ac.id/download/fkm-albiner.pdf.

Windayani dan Murtini. (2006). Kandungan Kadar Protein pada Bakso Ayam Broiler. Fakultas Peternakan Institut Pertanian Bogor, Bogor.

\begin{tabular}{|l|l|}
\hline Munassir B & $\begin{array}{l}\text { Program Studi Peternakan, Fakultas Pertanian, Peternakan dan Perikanan } \\
\text { Universitas Muhammadiyah Parepare } \\
\text { E-mail: } \underline{\text { munassir.b@gmail.com }}\end{array}$ \\
\hline Nurhaeda & $\begin{array}{l}\text { Program Studi Peternakan, Fakultas Pertanian, Peternakan dan Perikanan } \\
\text { Universitas Muhammadiyah Parepare } \\
\text { E-mail: } \underline{\text { munassir.b@gmail.com }}\end{array}$ \\
\hline Irmayani & $\begin{array}{l}\text { Program Studi Peternakan, Fakultas Pertanian, Peternakan dan Perikanan } \\
\text { Universitas Muhammadiyah Parepare } \\
\text { E-mail: } \underline{\text { munassir.b@gmail.com }}\end{array}$ \\
\hline
\end{tabular}

